Research Article

\title{
Digital transformation in assessment and evaluation course: The effects of Web 2.0 tools
}

\author{
Fatma Cumhur ${ }^{1}$ and Şefika Sümeyye Çam² \\ ${ }^{1}$ Muş Alpaslan University, Faculty of Education, Turkey (ORCID: 0000-0001-5891-564X) \\ ${ }^{2} \mathrm{Muş}$ Alpaslan University, Faculty of Education, Turkey (ORCID: 0000-0001-9360-0758)
}

\begin{abstract}
This study aims at using a Web 2.0 tool supported-application to achieve digital transformation in an assessment and evaluation course. The study explored the effectiveness of application on the academic achievement, attitude and views of student teachers. Following a mixed-method research design, the quantitative part comprised the pre-test-post-test quasi-experimental research with a control group and the qualitative part utilized a case study. The study was performed in the education faculty of a state university with a total of 52 student teachers ( 25 in the experimental group and 27 in the control group). While the courses were supported by Web 2.0 tools in the experimental group, traditional teaching methods were applied in the control group for a 14-week course period. The assessment and evaluation achievement test and attitude scale were used to gather quantitative data, while an interview form about the learning environment supported by Web 2.0 tools and the researcher observation notes were used to obtain qualitative data. For the quantitative part of the study, t-tests were computed and the qualitative data were analyzed through content analysis. The findings yielded a significant difference between the experimental and control groups in favor of the experimental group. The findings of the content analysis showed that experimental group student teachers found the Web 2.0 tools-supported course more enjoyable, effective and attention-taking. Based on these results, suggestions have been made to change the monotonous higher education courses and design them in a way that will attract the attention of students with Web 2.0 tools.
\end{abstract}

Keywords: Digital Transformation; Web 2.0 Tools; Assessment and Evaluation

Article History: Submitted 23 February 2021; Revised 2 June 2021; Published online 7 July 2021

\section{Introduction}

Technology has developed day by day and has become an indispensable part of human life. As in many fields, students easily adapt to technology, which is seen as an indispensable element of the education field. Students of this generation, often known as digital natives, rely on technology to get information and socialize in almost every aspect of their life (Jones, Johnson-Yale, Millermaier \& Perez, 2009). Transferring the technology, which is integrated into daily life, into curriculums is inevitable in terms of providing convenience in the learning process (Gill \& Dalgarno, 2017). In this regard, it is vital to train teachers that can meet the expectations of the technology era students.

Address of Corresponding Author

Fatma Cumhur, PhD, Department of Mathematics Education, Faculty of Education, Muş Alpaslan University, 49250 Güzeltepe, Muş, Turkey.

$\triangle$ cumhurfatma@gmail.com

How to cite: Cumhur, F. \& Çam, Ş. S. (2021). Digital transformation in assessment and evaluation course: The effects of Web 2.0 tools. Journal of Pedagogical Research, 5(3), 15-39. https:/ / doi.org/10.33902/JPR.2021370559 
Teachers of this age should be as much in touch with innovations as at least digital natives, must adopt technology and have 21st-century skills to adapt to the requirements of the age (Hunter, 2016). Considering the 21st-century skills, teachers should be able to use information and communication technologies (ICTs) efficiently in the learning-teaching process, select technologybased applications that are appropriate for the objectives of the course, follow new developments and continuously improve themselves and transfer the changes to -curriculums (Moundridou \& Papanikolaou, 2017).

Research shows that a significant number of teachers use technology only for purposes such as storing data, finding resources from the Internet and preparing presentations with PowerPoint (Jang \& Chen, 2010; Keengwe \& Georgina, 2012). In Turkey, a nationwide project called FATIH (Increasing Opportunities and Improving Technology Movement), aiming to increase the quality of teaching by providing the integration of technology to education, showed that teachers' educational technology knowledge was insufficient and the project could not proceed as expected (Altın \& Kalelioğlu, 2015). Although the technology infrastructure and equipment have been provided in schools, teachers who will use these technologies have not been adequately prepared for changing learning environments and more quantitative development has been achieved instead of the qualitative development targeted by the project (Başak \& Ayvac1, 2017).

Today, various training and programs are organized to increase the quality of education in a way to support teachers' knowledge of ICTs. However, although the majority of teachers exhibit positive attitudes and participate in these programs, they are not able to use the necessary knowledge and skills in their classrooms adequately. Some studies have shown that teachers feel nervous about using technology, are unable to adapt to change and cannot accept technology innovations due to insufficient support (Jang \& Chen, 2010; Lee \& Tsai, 2010; Niess, 2011). Tosuntaş, Çubukçu and İnci (2019) evaluated the barriers to technology integration in education using the categories determined by Hew and Brush (2007) and Belland (2009). Accordingly, the barriers to technology integration the first one is "resources" like as lack of technology, lack of access to existing technology, lack of administrative support, lack of technical support, lack of time for course preparation and inadequate software. The second one is "knowledge and skills" which is the barrier to technology integration is teachers' perceptions of their inadequacy or lack of knowledge and skills. The third barrier is "institution" which is called institutional barriers and includes educational policies of institutions and countries. The fourth barrier is "attitudes and beliefs" which is the important factors affecting individuals' use of technology are generally their attitudes and beliefs towards technology. The fifth barrier is "assessment" that teachers do not have enough time to plan and use technology in teaching because of national exams to evaluate students. The sixth barrier is "subject area culture" which is include own content, pedagogy and evaluation approach. The last barrier is "habitus" which is the tendencies that are formed as a result of the experiences of teachers in their own learning life. When the reasons for teachers' technological deficiencies are examined, it is seen that they do not receive training following the requirements of the developing technology age (Moundridou \& Papanikolaou, 2017). Teachers are expected to adapt to innovations such as the Movement to Increase Opportunities and Technology (FATIH) project and to create learning environments suitable for digital natives with 21st-century skills, but they are not trained in accordance with these skills and competencies (Jang \& Chen, 2010). Today, technology-based opportunities are still not being used adequately in teacher training programs (Çam \& Erdamar-Koç, 2021; Keengwe \& Georgina, 2012). Student teachers are trained using traditional methods; however, when they graduate, they are expected to teach with a constructivist, learner-centered and technology-oriented approach (Parette, Quesenberry \& Blum, 2010). Moreover, many programs do not take enough time and effort to train student teachers with educational technologies (Martin, 2015). Therefore, it is reasonable to conclude that there is a big gap between the outcomes of the teacher training system and the expectations of the digital age (Benson \& Ward, 2013; Hunter, 2016; Jang \& Chen, 2010). In order to fill this gap, teacher training programs need to be revised, i.e., it is essential to get technology support in teaching profession 
skills and to improve the knowledge of the field and to provide training on the preparation of technology-oriented teaching materials in all teacher training courses (Ersoy, Kabakç1-Yurdakul \& Ceylan, 2016; Hunter, 2016).

In Turkey, with the recent changes made in the teacher training programs, it is highlighted that "technology literacy" is expected and the name and content of the "Instructional Technologies and Material Design" course have been updated and a two-hour course under the name of "Instructional Technologies" has been included (The Council of Higher Education [YÖK], 2018). The transformation of technology into an increasing need has started to affect the regulations made in teacher training programs. It is unrealistic to provide student teachers with the necessary qualifications in just two hours of training. This situation negatively affects the anxiety of the candidates about the use of technology (Cabı \& Ergün, 2016). Teacher training programs should be renewed in order to evaluate this situation as an initial initiative and to progress. The research findings show that teachers' experiences in teacher training programs are important determiners affecting technology adaptation (Agyei \& Voogt, 2011; Brush \& Saye, 2009; Çubukçu, Tosuntaş, İnci, \& Kircaburun, 2017). For this reason, following the requirements of the digital age, teacher training programs should emphasize digital transformation and provide necessary adaptations not only in instructional technology course but also in pedagogical knowledge and content knowledge courses.

\subsection{Theoretical Background}

\subsubsection{Learning environments with digital transformation}

As individuals' needs for information differ, different tools such as audiovisual tools, digital information sources and multimedia are emerging (United Nations Educational, Scientific, and Cultural Organization [UNESCO], 2006). Contemporary learning approaches are also affected by these differences and thus qualifications such as "learning to learn" and "lifelong learning" have gained significance. The change in the concept of access to information and the concept of 'learning' draws attention to a new trend under the name of ICTs. The use of these technologies, which affect every aspect of human life in the teaching and learning process, is an important factor for digital transformation. ICTs are used both for accessing, transmitting and storing information; and for creating, sharing and changing information. Today, the most common tools used in ICTs are computers, tablets and mobile phones (Janjua, Li, \& Thomas, 2017).

With the development of ICTs, learning environments are reorganized to form individuals who have the responsibility to learn, question, criticize, solve problems, follow innovations, have creative thinking skills, research, as well as entrepreneurs and learners who can communicate effectively (Moundridou \& Papanikolaou, 2017; Tondeur vd., 2012). Therefore, what is expected of students from learning environments, which changes with digital transformation, is not to memorize information but to learn and learn to learn (Krumsvik, 2014).

\subsubsection{Web 2.0 in higher education}

Traditional methods are often insufficient to increase student teachers' interest in the lesson, keep their motivation high and ensure their active participation (Harris \& Hofer, 2011). Web 2.0 tools are seen as important to eliminate this shortcoming. Butler (2012) defines Web 2.0 as web-based applications that allow users to create content in online environments, which has provided students with some educational advantages such as online discussions and communication via social networks (Faizi, Chiheb, \& El Afia, 2015). In addition to these, many benefits of Web 2.0 in facilitating access to information, encouraging collaborative activities and providing low-cost training opportunities were mentioned (Faizi at al., 2015; Grosseck, 2009). Therefore, initiatives for students' active participation in the course have increased and the trend towards digital transformation in higher education has been increasing day by day (Parette et al., 2010). This has motivated many researchers to do research on the use of Web 2.0 tools in education (Bassani \& Barbosa, 2018; Bennett, Bishop, Dalgarno, Lim \& Newby, 2019; Waycott, \& Kennedy, 2012). 
Numerous experimental studies have revealed that Web 2.0 tools integrated into the educational environment have positive effects on students' achievement and attitudes (Brinkley-Etzkorn, 2018; Ertmer et al., 2011; Lin, Ganapathy \& Kaur, 2018; Virtanen \& Rasi, 2017; Zarzycka -Piskorz, 2016). Mouza, Karchmer-Klein, Nandakumar, Özden and Hu (2014) enriched the learning environment by using Web 2.0 tools in a study they conducted with student teachers. They found that this new environment attracted the attention of student teachers and increased their interest in the lesson.

When the studies are examined, Kahoot and Edmodo are among the most frequently used Web 2.0 tools. It was found that the learning environments prepared with Edmodo increased the student teachers' attitudes towards the lesson along with their learning responsibilities (Holland \& Muilenburg, 2011). Hamutoğlu \& Kiyıc1 (2017) also revealed in their research that Edmodo increased the collaborative learning levels of student teachers and developed positive opinions about the lesson. Dellos (2015), Johns (2015) and Licorish et al. (2018) differentiated the learning environment by using Kahoot, one of the Web 2.0 tools. According to the results of the previous research, the competitive environment created in the classroom attracted the attention of student teachers and the lesson became more enjoyable than traditional methods. In these studies, it was determined that interactive tools such as Kahoot provide active learning.

Additionally, some studies mentioned the benefits of Web 2.0 tools as well as potential difficulties such as Internet access shortage (Kale \& Goh, 2014), lack of knowledge about Web 2.0 tools (Koruyucu \& Karalar, 2017; Lee, Miller, Newnham, 2008), Web 2.0 difficulty in learning the tools (Grosseck, 2009). Dohn (2009) emphasized the ability and competence of users to use Web 2.0 tools for the integration of Web 2.0 into the educational environment.

Effective use of Web 2.0 tools has an important role in differentiating, enriching and making the courses more enjoyable (Hofer, Lee, Slykhuis \& Ptaszynski, 2016). The development of various Web 2.0 tools to accommodate this differentiation has provided a good opportunity to move lessons away from stereotypes. Web 2.0 tools provide opportunities such as bringing students 'ideas to a visual environment, allowing everyone to see the content, displaying students' different answers to the screen with online tests or open-ended questions. These affordances are important in terms of carrying learning to an interactive platform. In addition, moving the information and resources related to the course to a platform that students can always access and following the assignments online play an important role in carrying the learning environment beyond the classroom. Some Web 2.0 tools that offer such affordances are presented in Figure 1.

Web 2.0 tools must be effectively integrated into the design, implementation and evaluation stages of the course in order to create digital learning environments. Web 2.0 tools in Figure 1 are among the effective applications that can be used in the assessment and evaluation part of a course (Çam, 2019). Using these tools for assessment and evaluation purposes contributes to the learning and teaching process in terms of repetition, continuous reinforcement, effective use of time and providing quick feedback (Graziano, Foulger, Schmidt-Crawford \& Slykhuis, 2017; Harris \& Hofer, 2011; Kabakç1-Yurdakul et al., 2014). By utilizing Kahoot, Socrative, PollEverywhere and Google forms, students' previous knowledge about the subject can be determined at the beginning of the course, learning levels can be determined at the end of the course and thus students' lack of knowledge can be completed. Students can see each other's different answers and be aware of their mistakes easily. With Word Art Tagul, different thoughts whose answers are short can be put forward and it can be determined to what extent similar thoughts have accumulated. With I Mind Map, concept maps that reveal the main lines of the subject can be created and information that will provide the summary of the lesson can be presented online with Padlet. With Edmodo, resource access can be facilitated and students' follow-up can be moved online. It is also possible to ensure the active participation of students during the evaluation process with these applications. 
Figure 1

Web 2.0 tools for higher education that can be utilized in a digital learning environment

\begin{tabular}{|c|c|}
\hline КАHOOT & $\begin{array}{l}\text { - It is a game-based learning platform. } \\
\text {-It is used as an evaluation tool. } \\
\text { - Learning games are in the form of multiple choice or true/false } \\
\text { questions created by the teacher. }\end{array}$ \\
\hline SOCRATIVE & $\begin{array}{l}\text { - It is a learning platform where learning is reinforced via various } \\
\text { questions. } \\
\text {-Question types such as short answers and matching are included, } \\
\text { which maes it different from Kahoot. }\end{array}$ \\
\hline $\begin{array}{l}\text { POLL } \\
\text { EVERYWHERE }\end{array}$ & $\begin{array}{l}\text {-It is an online response tool that allows assessment of different types of } \\
\text { questions and student information. } \\
\text { - It can be used by integrating it into the PowerPoint presentation tool. }\end{array}$ \\
\hline $\begin{array}{l}\text { GOOGLE } \\
\text { FORMS }\end{array}$ & $\begin{array}{l}\text { - It is a form and survey management application included in the Google } \\
\text { Drive office suite. } \\
\text { - With this application, a questionnaire can be applied to students on a } \\
\text { desired topic, and students' opinions can be obtained about any topics } \\
\text { or the course. Therefore, the points where the opinions are concentrated } \\
\text { can be determined through the statistics created on the system. }\end{array}$ \\
\hline EDMODO & $\begin{array}{l}\text { - It is a "social learning platform" site for teachers, students and parents. } \\
\text { - Students can learn about the developments instantly, access the } \\
\text { resources whenever they want, and evaluate themselves objectively } \\
\text { with the available tests. }\end{array}$ \\
\hline PADLET & $\begin{array}{l}\text { - It is a digital board where text, video or pictures can be shared on any } \\
\text { subject. } \\
\text { - With the help of these boards, different ideas can be taken from } \\
\text { students, lists of different thoughts about the subject can be made and } \\
\text { discussion environments can be created. }\end{array}$ \\
\hline I MIND MAP & $\begin{array}{l}\text {-It is a mind mapping application and can be used to create an argument } \\
\text { or concept maps. }\end{array}$ \\
\hline $\begin{array}{l}\text { WORD ART } \\
\text { TAGUL }\end{array}$ & $\begin{array}{l}\text {-It is an online word cloud creation program. It is used to reveal different } \\
\text { ideas and to conduct brainstorming. }\end{array}$ \\
\hline
\end{tabular}

\subsection{Purpose of the Study}

In recent years, the use of Web 2.0 tools for assessment and evaluation has gained importance and efforts to improve the quality of education have increased (Canbazoğlu-Bilici, 2012; Kabakç1 Yurdakul et al., 2012; Uğurlu, 2009; Zengin, Bars \& Şimşek, 2017). In their research, Kompen, Edirisingha, Canaleta, Alsina \& Monguet (2019) reveal that the use of Web 2.0 tools in higher education institutions makes the courses more enjoyable, facilitates learning, ensures active participation of students and increases their attention and motivation. Lin, Ganapathy and Kaur (2018) and Zarzycka-Piskorz (2016) have found that students have more internalized the course and had fun as a result of their studies investigating the effect of gamification in higher education using Web 2.0 tools. Similarly, Frrat and Köksal (2017) and Efe (2014) concluded that student teachers use Web 2.0 tools mostly for entertainment, accessing information and web-based learning.

When the related literature is examined, it is seen that the use of Web 2.0 tools in higher education has benefits in terms of cooperation, motivation, attention, making the lesson fun and communication. Despite these educational benefits of Web 2.0 tools, there is not enough research on student teachers' awareness and competencies. The available studies are mostly for science courses and limited to few tools such as social networking, instant messaging and video sharing sites. Especially, there hasn't be found any study to support the assessment and evaluation course 
with web 2.0 tools. Based on this gap, this current study examines the effects of using Web 2. 0 tools, which are not commonly used in the literature, on student teachers' achievement, attitude and opinions towards the assessment and evaluation course. For this purpose, answers were sought for the following sub-problems:

1) When the academic achievement scores of the experimental group, in which teaching practices supported with Web 2.0 tools were carried out and the control group, in which teaching practices supported by traditional methods were carried out, are compared;

1a) Does it differ according to the groups (experiment-control)?

$1 b)$ Does it differ according to the measurements (pretest-posttest)?

2) When the attitudes of the experimental group, in which teaching practices supported with Web 2.0 tools were carried out and the control group, in which teaching practices supported by traditional methods, are compared;

2a) Does it differ according to the groups (experiment-control)?

2b) Does it differ according to the measurements (pretest-posttest)?

3)What are the opinions of the experimental group student teachers on the effectiveness of teaching practices supported by Web 2.0 tools?

4) What are the researchers' evaluations regarding the effectiveness of teaching practices supported by Web 2.0 tools?

\section{Method}

\subsection{Research Design}

This study used the mixed method research design in which quantitative and qualitative methods are used together. The goal of using mixed method researches is to provide a better understanding of research findings by using qualitative and quantitative research methods together and blended (Creswell, 2017). A sequential explanatory mixed-method research design was utilized (Creswell \& Plano Clark, 2011). Therefore, quantitative data was first collected and analyzed and then these data were supported with qualitative data to obtain more detailed information. This is followed by interpreting both quantitative and qualitative findings in relation to each other. The research design is summarized in Figure 2.

Figure 2

The research design

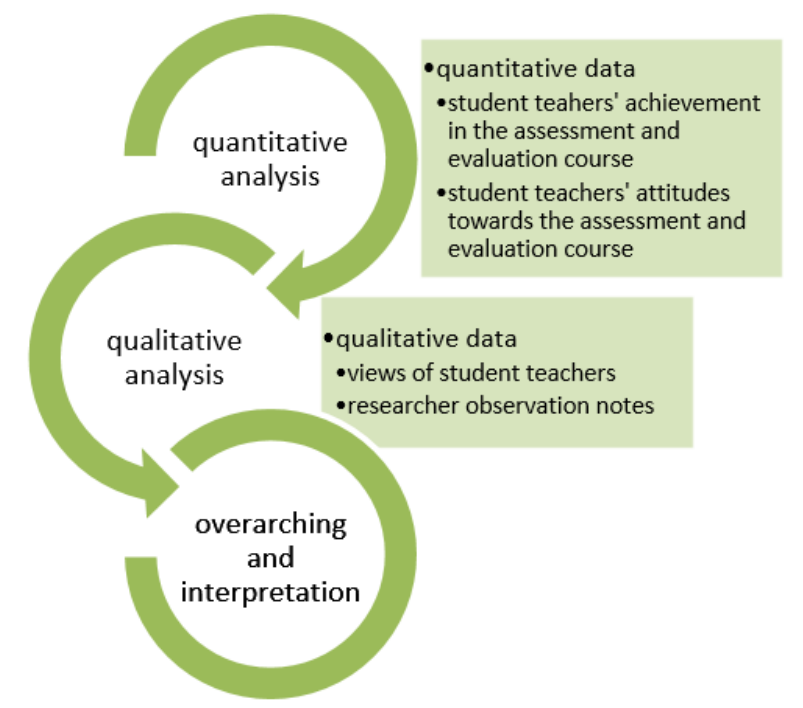

Quantitative data were obtained in the first stage of the research. This part comprised the pretest-post-test quasi-experimental research design with a control group. After the research process, a post-test is applied to evaluate the difference between the two groups (Creswell, 2005). In the second stage of the research, qualitative data were collected using a case study, which is one of the 
qualitative research methods. A case study is carried out to determine the real thoughts of the participants and to reveal the existing situation with all its reality (Yin, 1984).

\subsection{Participants}

The study group of the research consists of 52 student teachers studying at the education faculty of a state university which is located in the east part of Turkey. The participants are assigned to the experimental and control groups by considering the similarity of the fields, academic success levels and technological opportunities they have. Regarding these criteria, 25 student teachers from elementary mathematics teacher program and 27 student teachers from elementary science teacher program were included in the study. These programs were included in the study because both were taking the Assessment and Evaluation course from the same lecturer and the starting levels for this course were similar. An academic achievement test was applied to determine the starting levels of the participants and it was found that the groups were similar in terms of the pretest scores ( $p>$.05). Therefore, primary school mathematics students were selected as the experimental group and primary school science students were determined as control group randomly. The qualitative data were collected from 25 student teachers in the experimental group and their views were received about the study.

\subsection{The Research Process}

In the research, firstly the Web 2.0 tools used in the literature, nine Web 2.0 tools have been identified that will facilitate the transfer of the content of the Assessment and Evaluation course (see Figure 4). In order to use these tools more efficiently in the lessons, the general features of each tool were examined one by one and preliminary trials were made for the use of each tool before the lesson. The content of the prepared lesson was presented to the experts. Later, measurement tools to be used in the application process were prepared and validity and reliability studies were carried out. After the measurement tools were prepared, the experimental and control groups were determined. The "Assessment and Evaluation Achievement Test" and "Assessment and Evaluation Attitude Scale" were applied to both groups as pre-tests to both groups at the beginning of the process. While the courses were supported by Web 2.0 tools in the experimental group, traditional teaching methods were applied in the control group. The lessons of both groups were conducted by the first researcher who has experience in using Web 2.0 tools and specialized in assessment and evaluation. A course design supported by Web 2.0 tools was applied to the experimental group for 14 weeks (see Appendix 1). At the end of the treatment, a post-test was applied to both groups to determine the effect of the implementation made to the experimental group and the difference between the academic success of the groups and their attitude levels were examined. In addition, in order to obtain detailed information about the process and to determine the opinions of the participants, interviews were conducted with student teachers in the experimental group and researcher observation notes were kept.

\subsection{Teaching Process Designed with Web 2.0 Tools}

In the study Çam's (2019) study was used for the teaching process designed with Web 2.0 tools which included a total of 14 themes to provide digital transformation in higher education. A preliminary draft of the teaching content was prepared by selecting six themes suitable for the research (see Figure 3).

The class level was taken into account while designing the learning content. As a result of informal interviews with student teachers participating in the research the time allocated for research was kept flexible, considering that they took the Assessment and Evaluation course for the first time and did not use Web 2.0 tools before. The activities are designed to use digital tools by paying attention to the gains of the Assessment and Evaluation course. Therefore, discussion, demonstration, brainstorming and expression techniques were used. The Web 2.0 tools used and their usage purposes are summarized in Figure 3. 
Figure 3

Web 2.0 tools and their usage purposes in digital learning-based course content

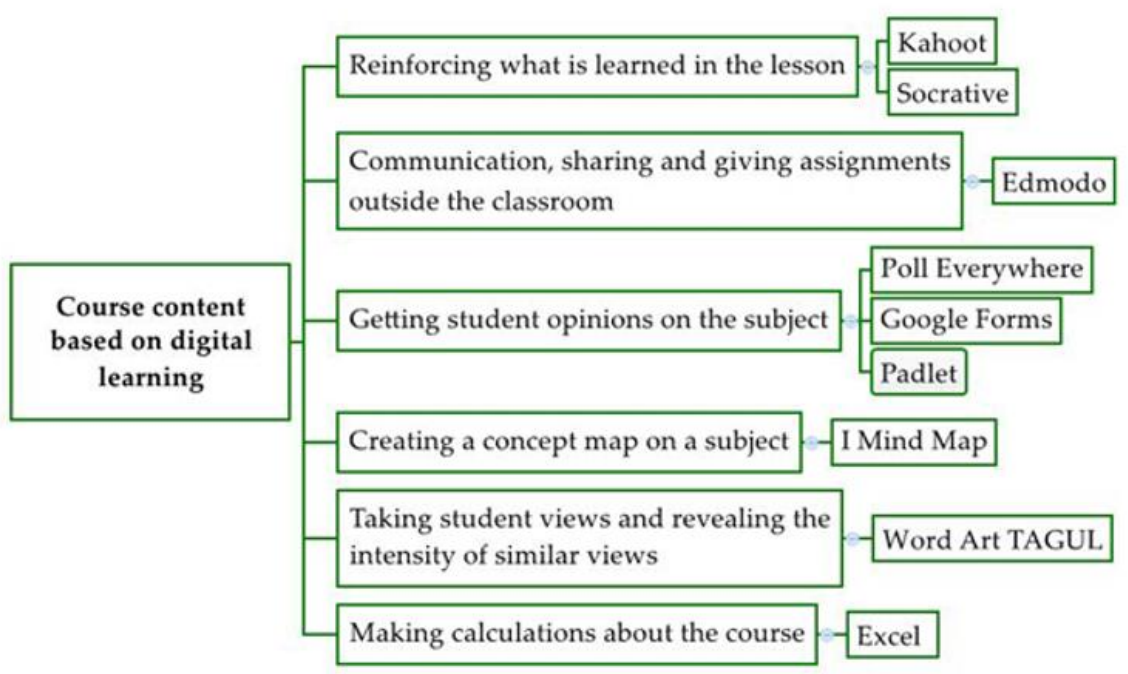

The subjects of the assessment and evaluation course and a suitable course plan were prepared for each subject. The prepared plans were presented to the expert opinions in the all field of the process. The detailed information on the 14-week implementation period is presented in table in the supplementary files section. Every week a 3-hour lesson plan was prepared in line with a theme and it is applied with the necessary materials. In the first week, students were informed about the Web 2.0 tools planned to be used throughout the semester. Then an Edmodo class was created to share about the course outside the class and to be in constant communication with them and all students were enrolled in this class. Other Web 2.0 tools used in the teaching process have been integrated into the course and used at appropriate points in the context of the course. Thus, while the tools used in the course are put into practice at the points deemed appropriate within the scope of the content, the tools used outside the class are mainly used for communication and homework.

\subsection{Data Collection Tools}

Quantitative data were collected through the "Assessment and Evaluation Achievement Test" and "Assessment and Evaluation Attitude Scale" and the qualitative data were collected via "Interview Form Regarding Learning Environment Supported by Web 2.0 Tools" and "Researcher Observation Notes."

\subsubsection{Assessment and evaluation achievement test}

An achievement test was developed to compare the achievements of the experimental and control group students. For this, first of all, the goals and behaviors of the course were determined by content analysis and 60 questions were written to measure these behaviors. Questions were presented to the opinion of three assessment and evaluation experts and one Turkish education specialist. As a result of the opinions of the experts, the trial form was reduced to 40 items and this form was applied to the 219 4th-year student teachers who were taking testing and evaluation course in the teacher education programs of Turkish, Mathematics, Science, Classroom and Preschool. In the trial test, item difficulty and discrimination indices of the questions were calculated. Twenty questions with the highest validity values were included in the final test. The 20-question achievement test discrimination power ranges from 0.30 to 0.69 and item difficulties range from 0.21 to 0.67 . KR-20 reliability of the test was calculated as 0.72 . 


\subsubsection{Assessment and evaluation attitude scale}

An attitude test, developed by Aktaş ve Alıcı (2012) was used to determine the effects of the implementation on the attitudes of the student teachers towards the Assessment and Evaluation course. The test, consisting of 20 items, consists of three factors. While the reliability value of the scale was 0.944 , the reliability values of the factors were $0.911,0.898,0.845$, respectively. In the research, the effect size value $\left(\eta^{2}=\frac{Z^{2}}{N}\right)$ regarding how effective the experimental procedure applied was also calculated. Fritz, Morris and Richler (2012) state that it is appropriate to calculate the effect size value for non-parametric tests according to the formula below. If the calculated value is $.10, .30$ and .50 , they interpret these values as "small", "medium" and "large" effect size.

\subsubsection{Interview form regarding learning environment supported by Web 2.0 tools}

An interview form was prepared to reveal the opinions of the experimental group student teachers about the Web 2.0 tools used. For this interview form prepared by the researchers, 14 open-ended questions were written by the literature review. A total of three experts were asked for their opinions. As a result of the opinions of the experts, questions that have a similar meaning and not suitable for the research questions are removed and the incomprehensible expressions were rearranged and as a result, a 10-question trial form was developed. The pilot implementation of the trial form was applied to four student teachers other than the study group and the final interview form included four questions after combining repetitive questions.

\subsubsection{Researcher observation notes}

The researcher, who carried out the implementation during the research period, received observation notes as participant observers. With these observations, the positive and negative effects experienced during the implementation were examined and additional support was provided to the information that could not be collected with quantitative data.

\subsection{Data Analysis}

In the study, quantitative data and qualitative data were analyzed separately and interpreted together.

\subsubsection{Analysis of the quantitative data}

In analyzing the quantitative data, the assumptions and descriptive statistics of the groups were examined to decide on the analysis and test techniques. Firstly, the normal distribution limits of skewness and kurtosis values of the pre-test - post-test scores of the Assessment and Evaluation Achievement Test were examined and found to be between $(-1,+1)$. According to the normality assumption Shapiro-Wilk test results, both experimental and control group pre-test post-test distributions are suitable for normal distribution $(p>0,05)$. Considering the obtained scores and the sample size, which is higher than 30, it was decided to use parametric tests (Büyüköztürk, Çokluk \& Köklü; 2010; Kalayc1, 2010). Since both the pre-test and post-test mean scores of the experimental group were higher than \pm 1 and the skewness value of the control group's post-test scores deviated from -1 , the study used not the t-test but Mann-Whitney $U$ non-parametric test in comparison of attitude scores.

\subsubsection{Analysis of the qualitative data}

Qualitative data were analyzed by content analysis. In content analysis, the aim is to reach concepts and relationships that can summarize the collected data (Yıldırım \& Şimşek, 2011). For this purpose, the data obtained from the interview form were subjected to content analysis. In the analysis of the data, the stages of description, classification and relationship building were followed (Dey, 2003). 
a) In the description stage, the course environment is depicted and the opinions of the participants are directly quoted. Participants' confidentiality was ensured by using codes such as ST1, ST2, ST3... when making direct quotations.

b) In the classification phase, all data are coded and analyzed one by one to explain each research question. The data were coded by two experts and a code matrix was created. Coding was found to be compatible with $91 \%$, which is sufficient when it is $70 \%$ and above (Miles \& Huberman, 2002).

c) In the relationship establishment, the relationships were investigated and then the codes, themes and categories were established.

Themes and sub-themes are expressed in frequencies in terms of frequency of repetition. It was taken into account that a comment may have more than one theme or sub-theme.

\subsection{Validity and Reliability}

In qualitative research which is a part of mixed research, validity and reliability studies are very important (Yıldırım \& Şimşek, 2011). In this regard, the validity and reliability of this research was prioritized. In order to ensure the credibility of the research, the diversification of data sources was used. All the data coming from the academic achievement test and open-ended questions were kept.

In this research, the same pretest-posttest was applied to the experimental and control groups. The learning process was also carried out by the same researcher. The same researcher and another researcher also took part in the evaluation process to increase reliability. Therefore, it has been tried to prevent elements that threaten internal validity.

The transferability of the research has been provided with a detailed description. For this, the research steps are explained in detail and direct quotations are included while analyzing the research data. In order to ensure consistency, the names of the students were kept confidential, coding was done by two researchers and the coding was checked repeatedly. Data related to the research were analyzed by two researchers at different times. The study was applied according to ethical rules and the volunteering of the participants was taken as a basis.

\section{Findings}

\subsection{Quantitative Findings}

In order to determine the academic achievement and attitude levels of student teachers of the assessment and evaluation course supported with the Web 2.0 tools applied in the research, the findings of the data collected with the assessment and evaluation achievement test and the assessment and evaluation attitude scale are presented in the following sections.

\subsubsection{The Effect of assessment and evaluation course supported by Web 2.0 tools on student teachers' academic achievement}

The first dependent variable investigated in the research is the assessment and evaluation achievement (AEA) of the student teachers. The quantitative data for this research problem was by the question of "Do the academic achievement scores of student teachers differ according to the groups (experiment-control) and measurements (pre-test-post-test) by using the teaching model based on digital learning in the Assessment and Evaluation course?" In order to better see the level of development of the AEA, the pre-test scores of the experimental and control groups, which are independent groups, were first compared. The results are shown in Table 1.

Table 1

Independent Samples t-test Results for the Experimental and Control Group AEA Pretest Scores

\begin{tabular}{|c|c|c|c|c|c|c|c|}
\hline Test & Groups & $n$ & $\overline{\bar{X}}$ & $S D$ & $d f$ & $t$ & $p$ \\
\hline \multirow[t]{2}{*}{ AEA pre-test } & Experimental group & 25 & 32.80 & 7.00 & \multirow[t]{2}{*}{50} & \multirow[t]{2}{*}{1.896} & \multirow[t]{2}{*}{0.064} \\
\hline & Control Group & 27 & 28.42 & 9.35 & & & \\
\hline
\end{tabular}


According to Table 1, when the pre-test results of the experimental and control groups are compared, it is seen that there is no statistically significant difference between the mean scores $[\mathrm{t}(50)=1.896, \mathrm{p}>0.05]$. When the pre-test mean scores are compared, $X_{\text {experimental }}=32.80 ; X_{\text {control }}=28.42$, it is seen that the two groups were close to each other. This result reveals that there is no significant difference between the achievements of the experimental and control groups before the applications. At the end of the application, independent groups $t-$ test was applied in order to examine the difference in AEA levels between the groups. The results are shown in Table 2.

Table 2

Independent Samples t-Test Results for the Experimental and Control Group AEA Post-Test Scores

\begin{tabular}{|c|c|c|c|c|c|c|c|}
\hline Test & Groups & $n$ & $\overline{\bar{X}}$ & $S D$ & $d f$ & $t$ & $p$ \\
\hline \multirow[t]{2}{*}{ AEA post-test } & Control Group & 25 & 58.40 & 13.51 & \multirow[t]{2}{*}{50} & \multirow[t]{2}{*}{2.203} & \multirow[t]{2}{*}{0.032} \\
\hline & Experimental Group & 27 & 49.62 & 15.05 & & & \\
\hline
\end{tabular}

As seen in Table 2, when the post-test results are compared, it is seen that there is a statistically significant difference between the post-test mean scores of the experimental and control groups $[t(50)=2.203, p<0.05]$. When the post-test averages are compared, it is seen that the experimental group is more successful than the control group $X_{\text {experimental }}=58.40 ; X_{\text {control }}=49.62$. This result shows that the implementation positively affected the experimental group and significantly increased the development of the student teachers' AEA levels. A paired-samples t-test was conducted to answer the following question: "Does the AEA differ in the experimental group regarding the pre-test and post-test scores?" The results are shown in Table 3.

Table 3

Paired Samples t-Test Results Regarding the AEA of the Experimental Group

\begin{tabular}{|c|c|c|c|c|c|c|c|}
\hline Group & Test & $n$ & $\overline{\bar{X}}$ & $S D$ & $d f$ & $t$ & $p$ \\
\hline \multirow{2}{*}{$\begin{array}{l}\text { Experimental } \\
\text { Group }\end{array}$} & Pre-test & \multirow{2}{*}{25} & 32.80 & 7.00 & \multirow[t]{2}{*}{50} & \multirow[t]{2}{*}{-8.921} & \multirow[t]{2}{*}{0.00} \\
\hline & Post-test & & 58.40 & 13.51 & & & \\
\hline
\end{tabular}

When Table 3 is examined, it is seen that there is a statistically significant difference between the pre-test and post-test mean scores of the experimental group [ $t(50)=-8,921, p<0.05]$. In other words, the implementation carried out in the experimental group significantly increased the development of the student teachers' AEA levels. A paired-samples t-test was conducted to answer the following question: "Does the AEA differ in the control group regarding the pre-test and posttest scores?" The results are shown in Table 4.

Table 4

Paired Samples t-Test Results Regarding the AEA of the Control Group

\begin{tabular}{|c|c|c|c|c|c|c|c|}
\hline Group & Test & $n$ & $\overline{\bar{X}}$ & $S D$ & $d f$ & $t$ & $p$ \\
\hline \multirow[t]{2}{*}{ Control Group } & Pre-test & \multirow{2}{*}{27} & 28.42 & 9.35 & \multirow[t]{2}{*}{50} & \multirow[t]{2}{*}{-6.240} & \multirow[t]{2}{*}{0.00} \\
\hline & Post-test & & 49.62 & 15.05 & & & \\
\hline
\end{tabular}

As it is seen in Table 4, there is a statistically significant difference between the pre-test and post-test mean scores of the control group [ $\mathrm{t}(50)=-6,240, \mathrm{p}<0.05]$. In other words, traditional practices carried out in the control group significantly increased the development of the student teachers' AEA levels. 
3.1.2. The effect of assessment and evaluation course supported by Web 2.0 tools on student teachers' attitude levels towards the course

The findings obtained in order to determine the effects of applications supported by Web 2.0 tools on the attitude levels of student teachers towards the Assessment and Evaluation course are presented in Table 5.

Table 5

Descriptive Statistics of the Scores of the Experimental and Control Groups on the Assessment and Evaluation Course Attitude Scale

\begin{tabular}{lllcccc}
\hline Groups & Test & $n$ & $\bar{X}$ & SD & Skewness & Kurtois \\
\hline \multirow{2}{*}{ Experimental } & Pre-test & 25 & 65.40 & 6.72 & -.470 & -.288 \\
& Post-test & 25 & 73.16 & 3.73 & 1.180 & 1.770 \\
\hline \multirow{2}{*}{ Control } & Pre-test & 27 & 66.59 & 7.09 & -.077 & .941 \\
& Post-test & 27 & 61.96 & 11.48 & -1.026 & .600 \\
\hline
\end{tabular}

Table 5 shows descriptive statistics about the scores of the participants in the experimental and control groups from the attitude scale towards the Assessment and Evaluation course. When the pre-test scores of the experimental and control groups are examined, it is seen that there is a small score difference between the groups. In addition, the distribution of the data belonging to the groups was examined with the coefficient of skewness and kurtosis. When these values are examined, it is seen that both the pre-test and post-test mean scores of the experimental group are higher than \pm 1 of the skewness and kurtosis values. It is observed that the skewness value of the control group's post-test scores deviates from -1. Therefore, in comparing the attitude scores of the groups, the Mann-Whitney $U$ test, which is one of the non-parametric techniques, was used instead of the t-test and the results are summarized in Table 6.

Table 6

Comparison of the Scores of the Experimental and Control Groups on the Assessment and Evaluation Course Attitude Scale

\begin{tabular}{llcccccc}
\hline Test & Groups & $n$ & Mean Rank & Rank Sum & U & $Z$ & $p$ \\
\hline Pre-test & Experimental & 25 & 25.54 & 638.50 & 313.500 & -.441 & .659 \\
& Control & 25 & 27.39 & 739.50 & & & \\
\hline Post-test & Experimental & 27 & 35.18 & 879.50 & 120.500 & -3.987 & .000 \\
& Control & 27 & 18.46 & 498.50 & & & \\
\hline
\end{tabular}

As Table 6 indicates, no statistically significant difference between the rank sum of the pre-test scores of the experimental and control groups is found $(U=313,500 ; p>.05)$. However, when the post-test scores of both groups are examined, it is observed that the difference in scores observed between the experimental and control groups is statistically significant ( $U=120,500 ; p<.01)$. In other words, it can be said that the experimental process applied by the researchers contributed to the positive development of the attitudes of the participants in the experimental group towards the assessment and evaluation lesson. As a final remark, effect size coefficient calculated for this study is .30. Based on this, it can be said that the experimental procedure applied to the experimental group has a "medium" effect size. In other words, Assessment and Evaluation course application supported by Web 2.0 tools explains $30 \%$ of the academic achievement points of the students in the experimental group.

\subsection{Qualitative Findings}

In order to support quantitative data and obtain more in-depth information, the findings obtained through interviews with the experimental group and researcher observation notes are presented below. 


\subsubsection{Perceptions of student teachers for the assessment and evaluation course supported by Web 2.0 tools}

In order to reveal the qualitative data of the research, the opinions of student teachers in the experimental group related to the teaching model based on digital learning were determined as the third sub-problem. For this purpose, the answers given by the student teachers to the four questions in the interview form were subjected to content analysis and some themes and subthemes were created. Firstly, student teachers were asked: "What do you understand from digital learning?" Findings related to this question are as in Table 7.

Table 7

Student Teachers' Perceptions of Digital Learning

\begin{tabular}{|c|c|c|c|}
\hline Theme & Sub-theme & Frequency $(f)$ & Total \\
\hline \multirow[t]{3}{*}{$\begin{array}{l}\text { Use of } \\
\text { technology }\end{array}$} & $\begin{array}{l}\text { Conducting the learning-teaching process using } \\
\text { computers, tablets and smartphones }\end{array}$ & 19 & \multirow[t]{3}{*}{26} \\
\hline & Obtaining technology information & 6 & \\
\hline & Using ICTs & 1 & \\
\hline \multirow[t]{3}{*}{$\begin{array}{l}\text { Digital } \\
\text { environment }\end{array}$} & $\begin{array}{l}\text { Execution of the learning-teaching process in the } \\
\text { digital environment }\end{array}$ & 8 & \multirow{3}{*}{10} \\
\hline & Providing information exchange with digital tools & 1 & \\
\hline & Active classroom participation through digital tools & 1 & \\
\hline \multirow[t]{3}{*}{$\begin{array}{l}\text { Virtual } \\
\text { environment }\end{array}$} & $\begin{array}{l}\text { Accessing documents related to the course outside the } \\
\text { course }\end{array}$ & 6 & \multirow{3}{*}{9} \\
\hline & To be able to repeat courses outside the class & 2 & \\
\hline & Simultaneous teaching in different places & 1 & \\
\hline \multirow{2}{*}{$\begin{array}{l}\text { Keeping up } \\
\text { with the age }\end{array}$} & Keeping up with current technologies & 3 & \multirow[t]{2}{*}{4} \\
\hline & Using current technologies in education & 1 & \\
\hline \multirow[t]{2}{*}{ Interaction } & Learning by interacting with fun & 2 & \multirow[b]{2}{*}{3} \\
\hline & $\begin{array}{l}\text { Interacting with technology applications in the } \\
\text { classroom }\end{array}$ & 1 & \\
\hline
\end{tabular}

Note: $\mathrm{f}$ value is not the number of people, but the frequency of expressions repeating. One person emphasized more than one expression.

As can be seen in Table 7, the opinions of the student teachers show that they attach different meanings to digital learning. It has been found that a vast majority of student teachers $(n=26)$ emphasized the "use of technology" while explaining the concept of digital learning, while others emphasized "digital environment," "virtual environment," "keeping up with age" and "interaction." This finding shows that the participants equate the use of technology in teaching with digital learning. The opinions of the participants supporting this finding are given below.

ST2: "Utilizing technology in the course and using applications such as Kahoot and Edmodo."

ST8: "Learning is done with the help of digital tools."

ST16: "It is the situation where technology is included in education and training."

The students of the experimental group, who expressed their opinions about defining digital learning environments, also expressed their opinions that this method can be used to adapt to the age and the interaction in the classroom can be increased. These opinions can be accepted as an indication that the research has a positive effect on the student teachers of the experimental group. As for the second question in the interview: "Which do you think are the most beneficial of the applications we use during the period? Why is that?" student teachers mentioned three applications with the highest frequency of repetition. The findings are presented in Table 8.

When Table 8 is analyzed, it can be seen that the participants liked Edmodo, Kahoot and Excel among the applications they used during the period. It is noteworthy that opinions about Edmodo 
Table 8

The Most Useful Web 2.0 Tools for Student Teachers

\begin{tabular}{llll}
\hline Theme & Sub-theme & Frequency $(f)$ & Total \\
\hline Edmodo & Communication & 11 \\
\cline { 2 - 3 } & Moving the course out of the class & 22 \\
\cline { 2 - 3 } & Learning responsibility & 5 \\
\cline { 2 - 3 } & Usability & 3 \\
\cline { 2 - 3 } & Active participation & 2 \\
\cline { 2 - 3 } & Interaction and sharing & 2 \\
\hline Kahoot & Fun & 7 \\
\cline { 2 - 3 } & Creating permanent information & 7 \\
\cline { 2 - 3 } & Competition & 3 \\
\cline { 2 - 3 } & Active participation & 3 \\
\cline { 2 - 3 } & Usability & 3 \\
\hline Excell & Facilitating learning & 3 \\
\cline { 2 - 3 } & Usability & 2 \\
\hline
\end{tabular}

Note: $f$ value is not the number of people, but the frequency of expressions repeating. One person emphasized more than one expression.

are more intense than others. Participants found this application useful in terms of allowing communication, out-of-class learning and gaining learning responsibility. They found Kahoot effective in terms of providing fun and permanent information. It was emphasized that Excel and other applications are more effective in terms of usefulness. It is understood that student teachers find the applications that allow useful communication, reinforcing the lesson and used for repetition more useful. Some of the representative views explaining this situation are as follows:

ST2: "Edmodo. This is because tests can be solved in an interactive environment according to the pace of the person, thousands of resources can be accessed and teachers can easily communicate with students on important topics."

ST4: "Edmodo and Kahoot because in Edmodo, communication between groups, sharing of lecture notes, quizzes we have solved have been very beneficial. Then Kahoot helped us connect with our phones during the lesson and answer questions."

Although it was understood that the opinions of the participants were positive, a third question: "What were the positive and negative effects of the digital learning tools we used during the period?" was asked. The responses to this question are given in Table 9.

Table 9

Positive and Negative Aspects of Using Web 2.0 Tools in the Classroom

\begin{tabular}{|c|c|c|c|}
\hline Theme & Sub-theme & Frequency (f) & Total \\
\hline \multirow[t]{5}{*}{ Positive views } & Facilitating learning & 20 & \multirow{5}{*}{49} \\
\hline & Enriching the course & 12 & \\
\hline & Ease of access to information & 9 & \\
\hline & Increasing interest and motivation & 6 & \\
\hline & Increasing interaction & 2 & \\
\hline \multirow[t]{4}{*}{ Negative views } & $\begin{array}{l}\text { Internet connection and other equipment } \\
\text { problems during the application }\end{array}$ & 20 & \multirow{4}{*}{28} \\
\hline & Time wasting & 5 & \\
\hline & Competition & 2 & \\
\hline & $\begin{array}{l}\text { Communication problem in extracurricular } \\
\text { applications }\end{array}$ & 1 & \\
\hline
\end{tabular}

Note: $f$ value is not the number of people, but the frequency of expressions repeating. One person emphasized more than one expression. 
As seen in Table 9, the participants mainly have positive views. Experimental group student teachers reported that digital applications facilitate learning, enrich the lesson, provide access to information, increase interest and motivation and increase interaction. In particular, opinions are concentrated in the sub-themes of "Facilitating Learning" and "Enriching the Course". It can be said that factors such as interactive digital tools, rich visual materials and involvement are important factors in facilitating learning. It is one of the important findings that emphasize the concept of "reinforcement" among the positive opinions of the applications. This finding reveals that practices aimed at asking questions and making suggestions lead to success. Also, student teachers believe that such applications increase the ease of access to information, increase motivation by making the course more enjoyable. Below are some quotes from the positive opinions of the participants:

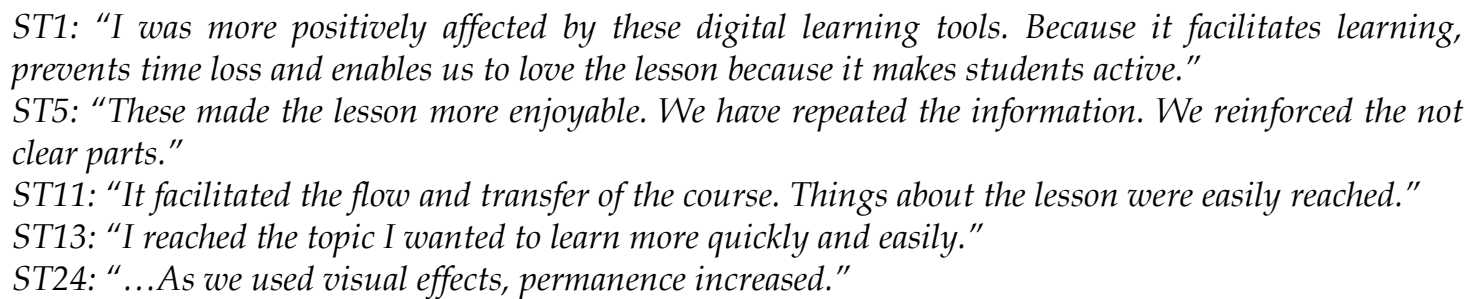

On the other hand, it is seen that the negative opinions about the applications are mostly gathered under the sub-theme of "Internet connection and other equipment problems during the application". The necessity of internet access both inside and outside the classroom to access the digital applications used caused the participants to have problems during the times in which they did not have access to the Internet. Negative views were mainly about the give error issues, launching the application and the necessity of precision. In addition to these, some student teachers' lag behind practices are among the other negative opinions expressed. Some participants drew attention to the problems experienced in technological tools due to reasons such as the smart board does not open and there are power cuts. Another important issue regarding negative views is related to loss of time. At the beginning of the course, there was a loss of time during the preparation of the Internet and other equipment or adaptation during the application and it was understood that there were problems in the classroom discipline. Some of the views reflecting the negative opinions about the applications are given below:

ST10: "Sometimes there is an internet problem on the smart board. This causes delays in the lesson."

ST16: "Due to minor malfunctions, Kahoot caused a waste of time in the lesson. Not knowing all the features of the applications we use has resulted in losing time."

ST17: "Internet access was a problem. Sometimes we could not pick the option."

ST22: "Sometimes the Internet did not work and I was not familiar with computer technologies."

Although the positive views of the student teachers about the practices in the research are dominant, their negative views are not negligible. It can be thought that this situation arises since classroom equipments are not sufficiently prepared and student teachers' encountered these practices for the first time. As a result of this experience, the participants were asked to answer this fourth question: "When you become a teacher, would you consider using the learning tools you see in this lesson? Explain for reasons." Answers to this question are classified into two sub-themes, "I use" and "I don't use," and the findings are presented in Table 10.

As Table 10 indicates, the majority of student teachers participating in the research consider implementing digital applications when they are appointed. They prefer using these Technologies as they help in facilitating learning, making the lesson attractive, making the lesson enjoyable, using time effectively, ensuring active participation, adapting to the requirements of the age and facilitating the presentation of information. Below are some views of this finding. 
Table 10

Student Teachers' Views About Using Web 2.0 Tools

\begin{tabular}{llll}
\hline \multirow{2}{*}{ Theme } & \multicolumn{1}{c}{ Sub-theme } & Frequency $(\mathrm{f})$ & Total \\
\hline I use & Facilitating learning & 11 \\
\cline { 2 - 3 } & Make the course interesting & 7 \\
\cline { 2 - 3 } & Make the lesson fun & 6 \\
\cline { 2 - 3 } & Using time effectively & 3 \\
\cline { 2 - 3 } & Ensuring active participation & 2 \\
\cline { 2 - 3 } & Adapting to the requirements of the age & 2 \\
\cline { 2 - 3 } & Making it easier to present information & 2 \\
\hline I do not use & Time wasting & 3 \\
\cline { 2 - 3 } & Insufficient tools & 1 \\
\cline { 2 - 3 } & Limited use & 1 \\
\cline { 2 - 3 } & Not complying with age level & \\
\hline
\end{tabular}

Note: $\mathrm{f}$ value is not the number of people, but the frequency of expressions repeating. One person emphasized more than one expression.

ST1: "I definitely use them because I think they will make students love the lesson and prevent time loss."

ST5: "Yes, because we make the lesson more enjoyable and productive, facilitate learning; we keep up with today's age."

OA9: "Yes, because I found it useful, it reinforces learning and makes it permanent."

Some participants, who did not want to use the applications, suggested the reasons for loss of time, insufficient equipment, limited use and non-compliance with the age level. The inadequate conditions and accordingly, the loss of time left the student teachers abstaining from using these tools.

ST6: "I prefer to tell myself on the board; maybe I just use Edmodo for tests."

ST23: "No, because I will probably have illiterate students in a village school."

\subsubsection{Researcher's observation notes in the Web 2.0 tools supported the assessment and evaluation course}

The findings obtained as a result of the observations made by the researcher throughout the study were examined under two themes as the positive and negative effects of digital learning environments. Results from these observation notes are summarized as in Figure 4.

Figure 4

Researcher's observation notes in the Web 2.0 tools supported the assessment and evaluation course

The positive effects of digital learning

The digital learning environment was effectively implemented in assessment and evaluation lesson

\begin{tabular}{|c|}
\hline Students actively participated \\
\hline Students showed interest \\
\hline Theory was practiced \\
\hline
\end{tabular}

Student teachers had fun
The negative effects of digital learning

Student teachers s' level of readiness to use digital tools was low

There was time wasting

There was internet connection problem

Students were affected by each other's views 
A course that requires practice with students such as Assessment and Evaluation was carried out with digital learning tools, students' active participation was provided with instant feedback and their interest was attracted to the course. The fact that the course is suitable for statistical thinking and calculation has been demonstrated to be very useful to use digital learning tools such as Google Forms and Excel. In addition, visualization of numerical data with graphics and charts has been effective in practicing the theory.

During the application, the whole class found the course different and focused on the course. In particular, it attracts the attention that students have fun in competition-style applications such as Kahoot. This shows that the course is interesting for the students.

In this course, carried out with Web 2.0 tools, participants had difficulty in adapting to the applications because their inadequate readiness levels. In order to realize these practices, the participants were given preliminary information, but due to this, a time problem occurred. Experiencing the infrastructure problem in the application environment also caused time loss. Poor internet connection in the classroom caused complexity during applications. Finally, it was determined that the student teachers were influenced by each other's writing while the results were reflected on the blackboard during the applications made to determine the students' ideas and answers.

\section{Discussion and Conlusion}

The use of Web 2.0 tools has gained importance with the developments in technology and digitalization in higher education all over the world, including Turkey. This situation necessitates the of using Web 2.0 tools in teaching processes along with distance education. The most common conclusion reached from the findings of this current study, which aims to raise individuals who can use Web 2.0 tools in the new generation teacher training system, is that learning environments designed with Web 2.0 tools increase academic success and affect both the attitude towards the lesson and the opinions positively.

According to the results of the research, in the success and attitude test applied after the experimental process, it is seen that the post-test scores of the experimental group students who passed through the learning process designed with Web 2.0 tools were higher and meaningful than those of the control group students who passed through the learning process using traditional methods. This finding revealed that the learning process designed with Web 2.0 tools is effective in terms of increasing academic success and attitude towards the assessment and evaluation course. In the literature, some studies conclude that Web 2.0 tools have positive effects on academic achievement and course attitude (Brinkley-Etzkorn, 2018; Göker \& İnce, 2019; Karaoğlu, 2008; Lim \& Newby, 2019; Lin et al., 2018; Mouza et al., 2014; Sheffield et al., 2015; Zarzycka-Piskorz, 2016), as well as studies that contradict these findings (Batıbay, 2019; Korkmaz et al., 2019). The effect of the applied methods depends on the combination of many factors, such as the type of Web 2.0 tools used, the content of the course, the level of students' digital literacy and time. Factors that help student teachers' academic success and positive attitudes towards the course are that Web 2.0 activities are different and remarkable compared to traditional methods, they ensure active participation in the lesson and make the lesson enjoyable. The fact that students perform different practices in the lesson directly affected their positive attitude development. Because of the negative factors caused by not going out of the traditional methods, students can develop a positive attitude towards the lesson only if they can actively participate in the lesson with attention-grabbing practices (Çam, 2019; Keengweve \& Georgina, 2012). Siau et al. (2006) also found that mobile assisted assessment and evaluation practices significantly increased student participation, contributed to the development of learning and, accordingly, increased academic achievement and interest in the lesson. In addition, as stated by Kale and Goh (2014), it can be interpreted that the learning needs of students about using Web 2.0 make the use of these tools more attractive.

According to the qualitative data collected in the research, most of the student teachers explained the concept of digital learning with the 'use of technology'. It is reasonable to conclude 
that the reason why participants associate the concept of digital learning with the use of technology is that they use ICTs such as mobile phones, computers and tablets throughout the research process. However, it is not the tools such as "technology" that should be focused on in every field where the concept of "learning" is, but the learning process itself (Harris \& Hofer, 2011). However, as in this research, in some studies (Ersoy et al., 2016; Koehler \& Mishra, 2005), in the learning environments provided with technology support, learners focused on technology, not learning. Many studies in the literature have similarly revealed that digital learning environments are directly associated with technology and the concept of learning is left behind (Benson \& Ward, 2013; Koh \& Divaharan, 2011). Studies revealing the other way around (Harris \& Hofer, 2011; Mouza et al., 2014) emphasized that Web 2.0 tools are used effectively with appropriate pedagogical methods, all digital applications used after focusing on learning remain a tool and students' perceptions are concentrated in the learning dimension.

One of the most notable findings is that student teachers find Edmodo, Kahoot and Excel more functional than other applications among the applications they have seen during the period. Edmodo has been found effective in terms of communication, sharing and active participation. Previous studies showed that Edmodo is beneficial in supporting students' collaboration (Holland \& Muilenburg, 2011) and it helps gain responsibility for learning (Sanders, 2012). Holland and Muilenburg (2011) have demonstrated that Edmodo is beneficial for students to support their work in cooperation and to gain students' responsibility for learning. Similarly, Hamutoğlu and Kiy1c1 (2017) achieved positive results in the usefulness of Edmodo. However, differently, the absence of a separate chat channel in Edmodo revealed that it negatively affects student-teacher communication. After Edmodo, the most liked and effective application was Kahoot.

Similarly, Kahoot, which has been found effective for reasons such as being fun, creating permanent information, creating competition and active participation, has been found useful in various studies (Dellos, 2015; Johns, 2015; Licorish at al., 2018; Mete \& Batibay, 2019; Polat, 2019; Yapic1 \& Karakoyun, 2017). Excel, on the other hand, has been seen as a beneficial and easy application in mathematics and assessment-evaluation courses that require calculations. Bozkurt and Cilavdaroğlu (2011), Kutluca (2013) and Baştürk and Yavuz (2008) also revealed that teachers use Excel in their lessons because it facilitates mathematical calculations, table creation and graphic drawing. Considering this information, it can be said that Web 2.0 tools, which provide active participation in assessment and evaluation courses, increase communication, provide entertainment and are easy to use, attract more attention from student teachers.

This situation also explains the finding regarding the student teachers' positive views. It was found that most of the student teachers' had positive views regarding the Web 2.0 tools used in the study. Opinions which had the highest frequency of repetition were about the effectiveness of Web 2.0 tools on making the learning easier and thus making the difficult subjects to understand easily. The feature of Web 2.0 tools being multifunctional and being used for various purposes in classes (Lim \& Newby, 2019) supports this view of the participants. Similarly, Baltaci-Göktalay and Özdilek (2010) and Brinkley-Etzkorn (2018) concluded that the Web 2.0 tools used in the research process facilitated learning and drew attention to the instructional aspect of these tools. Student teachers have drawn great attention to the fact that Web 2.0 tools enrich the lesson as well as facilitate learning. It has been emphasized in many studies that Web 2.0 tools, which allow different applications to be used in both visual and information reinforcement and transferring the course content, create rich environments in the course (Graziano at all, 2017; Grosseck, 2009; Jang \& Chen, 2010; Martin, 2015). This situation was directly noticed by the participants during the implementation process and had a positive effect on their opinions about the course. Moreover, it was determined that the assessment and evaluation course supported with Web 2.0 tools contributes to ease of access to information, making the lesson fun, increasing interest and motivation and communicating effectively. This finding is in line with the previous research findings, (e.g., Bolat et al., 2017; Kulaklı \& Mahony, 2014; Martin, 2015; Yapıc1 \& Karakoyun, 2017), in which it was found that courses that are designed with Web 2.0 tools increase motivation, 
improve learning and support broadened educational practices. The use of Web 2.0 tools in higher education for different purposes reveals that these tools have an important role in education (Baltac1-Göktalay \& Özdilek, 2010; Baran \& Ata, 2013; Çam, 2019; Grosseck, 2009; Horzum, 2010; Kulaklı \& Mahony, 2014). It can be said that the student teachers' active participation in the course and the fact that their opinions are valued with their practices as well as the interest and motivation play an important role in their positive opinions.

Although positive opinions are in the majority, some remarkable negative opinions were also found in this research. The most important of these are the connection problem in the learning environment and accordingly, the loss of time. Considering that the Internet is a key point for using Web 2.0 tools, it has been an inevitable problem for participants to lag behind applications when there is no or inadequate connection. This result overlaps with different research results in the literature, revealing the problem of internet connectivity and loss of time (Grosseck, 2009; Kale \& Goh, 2014; Karkoulia, 2016; Kulaklı \& Mahony, 2014). The deficiency of teacher training programs to integrate technology and the lack of infrastructure required for technology use in classrooms negatively affect digital learning environments (Jimoyiannis, 2010; Parette et al., 2010). Similar problems have been experienced in current research. Internet access, the lack of computers and other technology devices have made technology integration difficult in many studies (Akgün \& Çakal, 2013; Altın \& Kalelioğlu, 2015; Başak \& Ayvac1, 2017; Canbazoğlu-Bilici, 2012; Çınar et al., 2015). In some studies, it is concluded that although digital hardware and infrastructure problems are not experienced, digital learning environments are not sufficiently created (Bauer \& Kenton, 2005; Brinkley-Etzkorn, 2018). This circumstance demonstrates that the digital transformation process in educational institutions attempting to stay up with a new system is complex and a longterm phenomenon.

The problem of time loss due to internet connection can be explained by the fact that student teachers are attending a course designed with Web 2.0 tools for the first time and not having sufficient knowledge and skills. During the application, Web 2.0 tools could not be used directly, some preliminary information about the tools had been given to the student teachers. Therefore, the "technology knowledge" provided out of the course content caused a loss of time. Similarly, Bauer and Kenton (2005) concluded that student proficiency levels for technology integration are low. This reveals the need to improve student competencies in classes where Web 2.0 tools are applied. The problem of time experienced can also be explained by the findings of Baran and Ata (2013), who concluded that foreign language proficiency directly affects the level of using Web 2.0 tools. Teacher training programs have a considerable impact on the methods teachers use. The use of Web 2.0 tools in teacher training programs enables teachers who are trained to use these applications when they begin their profession (Baran et al., 2017; Gill \& Dalgarno, 2017). However, this requires a lot of time and applications (Baya'a et al., 2017). For this reason, student teachers participating in the current research can be enabled to practice more to solve the time loss problems experienced.

Lastly, when the plans of the student teachers were examined, it was found that the majority wanted to use Web 2.0 tools to comply with the requirements of the age, to provide learning with fun, to make students love the lesson and to make it enjoyable. This result is in line with the results of Vannatta and Beyerbach (2000), Baltacı-Göktalay and Özdilek (2010), Rienties et al. (2013) and Tatll et al. (2016). Therefore, it can be concluded that student teachers who receive training following the requirements of the age will teach as it should be done. In addition, there are some studies with negative opinions about using Web 2.0 tools in the future, since the ability to use these tools depends on technological and pedagogical knowledge (e.g., Koruyucu \& Karalar, 2017). This finding shows that one of the important factors that limit the use of Web 2.0 tools can be interpreted as lack of information and insufficient pre-service/in-service courses to complement this deficiency (Kale \& Goh, 2014). Considering that having experience in this subject will give educators more confidence, it is possible to provide more comprehensive adoption of Web 2.0 applications in the classroom, such as increased educational opportunities. 
The most important limitation of this research, which examines the effect of teaching supported by Web 2.0 tools on student teachers' success, attitude and opinions, is the use of only nine Web 2.0 tools, among many others. The implementation process can be observed in more detail, using more Web 2.0 tools. Other limitations are the participation of a limited number of candidates in the study and the fact that the study is conducted within a single course.

\section{Educational Implications and Future Research}

The major result of the current research revealed that student teachers in the experimental process who received Web 2.0 tools supported intervention the academic achievement level of the assessment and evaluation course statistically significant compared to those in the control group. Besides, participants in the experimental group developed a positive attitude towards the course, and indicated positive observations regarding the process. This reflects how receptive university students are to future breakthroughs. Therefore, in order to use Web 2.0 tools as a preliminary step in ensuring digital transformation in education faculties, instructors should be educated and professional development training should be provided to faculty members about the use of Web 2.0 tools in the courses by faculty deans or continuing education centers within the university. Lecturers should pay attention to this issue in order to go beyond straight lecturing methods and PowerPoint. Individuals who grew up in the age of technology now want to meet with differences, innovations and materials that will excite them. Thus, the methods applied in higher education should be reviewed and support should be obtained from Web 2.0 tools that will adapt to the age.

Another important result in the research is the lack of necessary infrastructure such as internet connection for using Web 2.0 tools. It is necessary to increase the initiatives of universities and schools to transform them into a technologically equipped structure. Internet connection problems in learning environments can be solved by controlling wireless networks in a controlled manner or by portable Wi-Fi devices carried by the instructor.

Time loss due to internet connection problems can be eliminated by providing the necessary learning environment conditions. However, student teachers' knowledge and skill levels for Web 2.0 tools should also be improved. For this, it is crucial to revise the curriculum of education faculties and courses such as assessment evaluation that requires calculations and active student participation. Therefore, the number of long-term studies to improve the knowledge and competencies of student teachers can be increased. In future studies, the effectiveness of different digital tools can be examined. Also, by adapting the same tools to different course contents, the change in student achievement can be analyzed.

\section{References}

Agyei, D., \& Voogt, J. (2011). Determining Teachers' TPACK through observations and self-report data. In M. Koehler \& P. Mishra (Eds.), Proceedings of SITE 2011--Society for Information Technology \& Teacher Education International Conference (pp. 2314-2319). Association for the Advancement of Computing in Education (AACE).

Akgün, Ö. E., \& Çakal, B. (2013, May 10-11). Investigation of the profciency of faculty members of education faculty according to technological pedagogical content knowledge model. [Conference presentation]. 6th National Postgraduate Education Symposium, Sakarya, Turkey. https://egitim.sakarya.edu.tr/sites/egitim.sakarya.edu.tr/file/ULES-Lisansustu_egitim_cilt11.pdf

Aktaş, M., \& Alıc1, D. (2012). Development of likert type attitude scale towards measurement and evaluation in education course. Journal of Qafqaz University, Philology and Pedagogy, 33, 66-73.

Altın, H. M., \& Kalelioğlu, F. (2015). Perceptions of students and teachers about FATIH project. Başkent University Journal of Education, 2(1), 89-105.

Baltac1-Göktalay, S., \& Özdilek, Z. (2010). Pre-service teachers' perceptions about Web 2.0 technologies. Procedia-Social and

https://doi.org/10.1016/j.sbspro.2010.03.760

$$
\text { Behavioral Sciences, 2(2), 4737-4741. }
$$


Baran, B., \& Ata, F. (2013). University students' Web 2.0 technologies usage, skill levels and educational usage. Education and Science, 38(169), 192-208.

Baran, E., Canbazoğlu Bilici, S., Albayrak Sarı, A., \& Tondeur, J. (2017). Investigating the impact of teacher education strategies on preservice teachers' TPACK. British Journal of Educational Technology, 50(1), 357370. https://doi.org/10.1111/bjet.12565

Bassani, P. B. S., \& Barbosa, D. N. F. (2018). Experiences with Web 2.0 in school settings: A framework to foster educational practices based on a personal learning environment perspective. Educação em Revista, 34, 1-27. https://doi.org/10.1590/0102-4698162010

Başak, M. H., \& Ayvac1, H. S. (2017). A comparison is aimed at the integration of the technology in education system; as an example of "Turkey and South Korea". Education and Science, 42(190), 465-492. http://dx.doi.org/10.15390/EB.2017.6710

Baştürk, S., \& Yavuz, İ. (2008, May 6-8). The difficulties of pre-service teachers in preparing lesson activities using the interactive geometry program. [Conference presentation]. 8th International Educational Technology Conference, Eskişehir, Turkey.

Batıbay, E. F. (2019). The impact of Web 2.0 applications on motivation and success in Turkish course: the example of Kahoot [Unpublished Doctoral Dissertation]. Hacettepe University Institute of Educational Sciences, Turkey.

Bauer, J., \& Kenton, J. (2005). Toward technology integration in theschools: Why it isn'thappening. Journal of Technology and Teacher Education, 13(4), 519-546.

Baya'a, N., Daher, W., Anabousy, R., \& Anabousy, A. (2017, February 1-5). The development of pre-service teachers' TPACK in the use of digital tools. [Conference presentation] Congress of the European Society for Research in Mathematics Education (CERME10), Dublin City University, Dublin. https://hal.archivesouvertes.fr/CERME10/public/CERME10_Complete.pdf

Belland, B. R. (2009). Using the theory of habitus to move beyond the study of barriers to technology integration. Computers \& Education, 52(2), 353-364. https:// doi.org/10.1016/j.compedu.2008.09.004

Bolat, Y. İ., Şimşek, O., \& Ülker, Ü. (2017). The impact of gamified online classroom response system on academic achievement and views about this system. Bolu Abant Izzet Baysal University Journal of Faculty of Education, 17(4), 1741-1761.

Bozkurt, A., \& Cilavdaroğlu, A. K. (2011). Mathematics and classroom teachers' perceptions of technology use and integration into their instruction. Kastamonu Education Journal, 19(3), 859-870.

Brinkley-Etzkorn, K. E. (2018). Learning to teach online: Measuring the influence of faculty development training on teaching effectiveness through a TPACK lens. The Internet and Higher Education, 38, 28-35. https://doi.org/10.1016/j.iheduc.2018.04.004

Brush, T., \& Saye, J. (2009). Strategies for preparing preservice social studies teachers to effectively integrate technology: Models and practices. Contemporary Issues in Technology and Teacher Education, 9(1), 46-59.

Butler, J. (2012). Grappling with change: Web 2.0 and teacher education. In D. Polly, C. Mims, \& K. A. Persichitte (Eds.), Developing technology-rich teacher curriculums: Key issues (pp. 135- 150). IGI Global.

Büyüköztürk, Ş., Çokluk, Ö., \& Köklü, N. (2010). Sosyal bilimler için istatistik [Statistics for social sciences]. Pegem.

Cabı, E., \& Ergün, E. (2016). The impact of instructional technologies and material development course on the teacher candidates' concern about using educational technologies. Başkent University Journal of Education, 3(1), 37-43.

Canbazoğlu Bilici, S. (2012). Preservice science teachers' technological pedagogical content knowledge and self-efcacy [Unpublished Doctoral Dissertation]. Gazi University Institute of Educational Sciences, Turkey.

Creswell, J. W., \& Plano Clark, V. L. (2011). Choosing a mixed methods design. Designing and conducting mixed methods research, 2, 53-106.

Creswell, W. J. (2007). Qualitative inquiry and research design - Choosing among five approaches (Second Edition). Sage.

Çam, Ş. S. (2019). A professional development program proposal for the development of technological pedagogical content knowledge of the teacher educators. (Unpublished Doctoral Dissertation). Gazi University Institue of Educational Sciences.

Çam, Ş. S., \& Erdamar- Koç, G. (2021). A needs analysis study on technological pedagogical content knowledge of faculty members. Education and Information Technologies, 1-27. https:// doi.org/10.1007/s10639-021-10540-0 
Çınar, M., Doğan, D., \& Seferoğlu, S. S. (2015, February 4-6). Digital tools in education: An evaluation about Google classroom application. [Conference presentation]. 17th Conference of Academic Informatics. Eskişehir, Turkey. https://ab.org.tr/kitap/ab15.pdf

Çubukçu, Z., Tosuntaş, Ş. B., İnci, T., \& Kırcaburun, K. (2017). Evaluation of instructional technology and material design course in terms of contribution to technology integration. Anatolian Journal of Educational Leadership and Instruction, 5(2), 29-41.

Dellos, R. (2015). Kahoot! A digital game resource for learning. International Journal of Instructional Technology and Distance Learning, 12(4), 49-52.

Dey, I. (2003). Qualitative data analysis: A user friendly guide for social scientists. Routledge.

Dohn, N. B. (2009). Web 2.0: Inherent tensions and evident challenges for education. International Journal of Computer-Supported Collaborative Learning, 4(3), 343-363. https:/ / doi.org/10.1007/s11412-009-9066-8

Efe, H. A. (2015). The relation between science student teachers' educational use of Web 2.0 technologies and their computer self efficacy. Journal of Baltic Science Education, 14(1), 142-154.

Ersoy, M., Yurdakul, I. K., \& Ceylan, B. (2016). Investigating preservice teachers' TPACK competencies through the lenses of ICT skills: An experimental study. Education and Science, 41(186), 119-135. https:// doi.org/10.15390/EB.2016.6345

Ertmer, P. A., Newby, T. J., Yu, J. H., Liu, W., Tomory, A., \& Lee, Y. M. (2011). Facilitating students' global perspectives: Collaborating with international partners using Web 2.0 technologies. The Internet and Higher Education, 14(4), 251-261. https:/ / doi.org/10.1016/j.iheduc.2011.05.005

Faizi, R., Chiheb, R., \& El Afia, A. (2015). Students' perceptions towards using Web 2.0 technologies in education. International Journal of Emerging Technologies in Learning, 10(6), 32-36.

Fırat, E. A., \& Köksal, M. S. (2017). The relationship between use of Web 2.0 tools by prospective science teachers and their biotechnology literacy. Computers in Human Behavior, 70, 44-50. https://doi.org/10.1016/j.chb.2016.12.067

Fritz, C. O., Morris, P. E., \& Richler, J. J. (2012). Effect size estimates: current use, calculations and interpretation. Journal of Experimental Psychology: General, 141(1), 2-18. https://psycnet.apa.org/doi/10.1037/a0024338

Gill, L., \& Dalgarno, B. (2017). A qualitative analysis of pre-service primary school teachers' TPACK development over the four years of their teacher preparation programme. Technology, Pedagogy and Education, 26(4), 439-456.

Göker, M., \& İnce, B. (2019). The use of Web 2.0 tools in teaching Turkish as a foreign language and its effect on academic achievement. Turkophone, 6(1), 12-22. https://doi.org/10.1080/1475939X.2017.1287124

Graziano, K. J., Foulger, T. S., Schmidt-Crawford, D. A., \& Slykhuis, D. (2017, March 5). Technology integration and teacher preparation: The development of teacher educator technology competencies [Conference presentation]. Society for Information Technology \& Teacher Education International Conference. Austin, TX, United States. https://www.learntechlib.org

Grosseck, G. (2009). To use or not to use Web 2.0 in higher education?. Procedia-Social and Behavioral Sciences, 1(1), 478-482. https:/ / doi.org/10.1016/j.sbspro.2009.01.087

Hamutoğlu, N. B., \& Kıyıc1, M. (2017). An exploration of university students' views regarding the use of Edmodo as an educational social network. Trakya Journal of Education, 7(2), 322-343.

Harris, J. B., \& Hofer, M. J. (2011). Technological pedagogical content knowledge (TPACK) in action: A descriptive study of secondary teachers' curriculum-based, technology-relate dinstructional planning. Journal of Research on Technology in Education, 43(3), 211-229. https://doi.org/10.1080/15391523.2011.10782570

Hew, K. F., \& Brush, T. (2007). Integrating technology into K-12 teaching and learning: Current knowledge gaps and recommendations for future research. Educational Technology Research and Development, 55(3), 223-252. https:// doi.org/10.1007/s11423-006-9022-5

Hofer, M., Lee, J. K., Slykhuis, D. A., \& Ptaszynski, J. (2016). Opportunities and challenges of TPACK-based Professional development on a global scale. In Herring, M., Koehler, M., \& Mishra, P. (Eds.). Handbook of technological pedagogical content knowledge (TPACK) foreducators (pp. 225-234). Routledge.

Holland, C. \& Muilenburg, L. (2011). Supporting Student Collaboration: Edmodo in the Classroom. In M. Koehler \& P. Mishra (Eds.), Proceedings of SITE 2011--Society for Information Technology \& Teacher Education International Conference (pp. 3232-3236). Association for the Advancement of Computing in Education (AACE).

Horzum, M. B. (2010). Investigating teachers' Web 2.0 tools awareness, frequency and purposes of usage in terms of different variables. International Journal of Human Sciences, 7(1), 603-634. 
Hunter, M. A. (2016). Innovative approaches to faculty development for technology integration: Evaluation of a threetiered model [Unpublished Doctoral Dissertation]. Fielding Graduate University, USA.

Jang, S., \& Chen, K. (2010). From PCK to TPACK: Developing a transformative model for pre-service science teachers. Journal of Science Education and Technology, 19(6), 553-564. https://doi.org/10.1007/s10956-0109222-y

Janjua, N., Li, Y., \& Thomas, M. (2017). Developing information and communication Technologies for education in Haiti. VA Engage Journal, 5(1), 1-13.

Jimoyiannis, A. (2010). Designing and implementing an integrated technological pedagogical science knowledge frame work for science teachers professional development. Computers $\mathcal{E}$ Education, 55, 1259 1269. https://doi.org/10.1016/j.compedu.2010.05.022

Johns, K. (2015). Engaging and assessing students with technology: a review of Kahoot! Delta Kappa Gamma Bulletin, 81(4), 89-91.

Jones, S., Johnson-Yale, C., Millermaier, S., \&Pérez, F. S. (2009). US college students' Internet use: Race, gender and digital divides. Journal of Computer-Mediated Communication, 14(2), 244-264. https://doi.org/10.1111/j.1083-6101.2009.01439.x

Kabakçı-Yurdakul, I., Çoklar, A. N., Birinci, G. \& Kılıçer, K. (2012). Effect on technopedagogical education for preservice teachers and a model suggestion for technopedagogical education. TUBITAK Project (Project Number: 109K191).

Kabakçı-Yurdakul, I., Odabaşı, H. F., Kılıçer, K., Çoklar, A. N., Birinci, G., \& Kurt, A. A. (2014). Constructing technopedagogical education based on teacher competencies in terms of national standards. Elementary Education Online, 13(4), 1185-1202.

Kalaycı, Ş. (2010). SPSS uygulamalı çok değişkenli istatistik teknikleri [Applied multivariate statistics techniques with SPSS]. Asil.

Kale, U., \& Goh, D. (2014). Teaching style, ICT experience and teachers' attitude stoward teaching with Web 2.0. Education and Information Technologies, 19(1), 41-60. https:// doi.org/10.1007/s10639-012-9210-3

Karaoğlu, A. (2008). The effect of web-based education on the achievement level of computer course at primary level. [Unpublished Master Thesis]. Bahcesehir Univerisity, Turkey.

Karkoulia, K. C. (2016). Teachers' attitudes towards the integration of Web 2.0 tools in EFL teaching. Research Papers in Language Teaching and Learning, 7(1), 46-74. https:/ / doi.org/10.1007/s10639-011-9164-x

Keengwe, J., \& Georgina, D. (2012). The digital course training workshop for online learning and teaching. Education and Information Technologies, 17(4), 365-379. https://doi.org/10.1007/s10639-011-9164$x$

Koehler, M. J., \& Mishra, P. (2005). What happens when teachers design educational technology? The development of technological pedagogical content knowledge. Journal of Educational Computing Research, 32(2), 131-152. https:/ / doi.org/10.2190/0EW7-01WB-BKHL-QDYV

Koh, J. H., \& Divaharan, H. (2011). Developing pre-service teachers' technology integration expertise through the TPACK-developing instructional model. Journal of Educational Computing Research, 44(1), 3558. https:// doi.org/10.2190/EC.44.1.c

Kompen, R. T., Edirisingha, P., Canaleta, X., Alsina, M., \& Monguet, J. M. (2019). Personal learning Environmentsbased on Web 2.0 services in higher education. Telematics and Informatics, 38, 194-206. https://doi.org/10.1016/j.tele.2018.10.003

Korkmaz, O., Vergili, M., Çakır, R., \& Erdoğmuş , U. F . (2019). The impact of Plickers Web 2.0 assessment and evaluation tool on exam anxiety and academic success of students. Gazi Journal of Education Sciences, 5(2), 15-37. https://dx.doi.org/10.30855/gjes.2019.05.02.002

Koruyucu, A. T., \& Karalar, H. (2017). Primary school instructors' aspects towards Web 2.0 technologies. Trakya Journal of Education, 7(2), 456-474.

Krumsvik, R. J. (2014). Teacher educators' digital competence. Scandinavian Journal of Educational Research, 58(3), 269-280. https:// doi.org/10.1080/00313831.2012.726273

Kulakli, A., \& Mahony, S. (2014). Knowledge creation and sharing with Web 2.0 tools for teaching and learning roles in so-called University 2.0. Procedia-Socialand Behavioral Sciences, 150, 648-657.

Kutluca, T. (2013). Designing a computer asssited instructional material is developed by excel software. Electronic Journal of Education Sciences, 2(4), 40-49.

Lee, M. H., \& Tsai, C. C. (2010). Exploring teachers' perceived self efficacy and technological pedagogical content knowledge with respect to educational use of the World Wide Web. Instructional Science, 38(1), 121. https:// doi.org/10.1007/s11251-008-9075-4 
Lee, M. J., Miller, C., \& Newnham, L. (2008). RSS and content syndication in higher education: Subscribing to a new model of teaching and learning. Educational Media International, 45(4), 311-322. https://doi.org/10.1080/09523980802573255

Licorish, S. A., Owen, H. E., Daniel, B. \& George, J. L. (2018). Students' perception of Kahoot!'s influence on teaching and learning. Research and Practice in Technology Enhanced Learning, 13(9), 1-23. https://doi.org/10.1186/s41039-018-0078-8

Lim, J., \& Newby, T. J. (2019). Preservice teachers' Web 2.0 experiences and perceptions on Web 2.0 as a personal learning environment. Journal of Computing in Higher Education, 32, 234-260. https://doi.org/10.1007/s12528-019-09227-w

Lin, D. T., Ganapathy, M. \& Kaur, a. M. (2018). Kahoot! it: Gamification in higher education. Pertanika Journels Social Sciences \& Humanities, 26(1), 565-582.

Martin, B. (2015). Success ful implementation of TPACK in teacher preparation programs. International Journal on Integrating Technology in Education (IJITE), 4(1), 17-26.

Mete, F. \& Batıbay, E., F. (2019). The impact of Web 2.0 applications on motivation in the Turkish course: The Kahoot example. Journal of Mother Tongue Education, 7(4), 1029-1047.

Miles, M. \& Huberman, A. (2002). Reflections and advice. In Huberman, A. M., \& Miles, M. B. (Eds.), The qualitative researcher's companion (pp. 392-397). SAGE Publications, Inc.

Moundridou, M., \& Papanikolaou, K. A. (2017, April 25-28). Educating engineer educators on technology enhanced learning based on TPACK [Conference presentation]. Global Engineering Education Conference (EDUCON), Athens, Greece. https://ieeexplore.ieee.org/xpl/mostRecentIssue.jsp?punumber=7936435

Mouza, C., Karchmer-Klein, R., Nandakumar, R., Ozden, S. Y., \& Hu, L. (2014). Investigating the impact of an integrated approach to the development of preservice teachers' technological pedagogical content knowledge (TPACK). Computers \& Education, 71, 206-221. https://doi.org/10.1016/j.compedu.2013.09.020

Niess, M. L. (2011). Investigating TPACK: Knowledge growth in teaching with technology. Journal of Educational Computing Research, 44(3), 299-317. https:// doi.org/10.2190/EC.44.3.c

Parette, H. P., Quesenberry, A. C., \& Blum, C. (2010). Missing the boat with technology usage in early childhood settings: A 21st century view of developmentally appropriate practice. Early Childhood Education Journal, 37(5), 335-343. https:// doi.org/10.1007/s10643-009-0352-x

Polat, M. (2019). Use or not use Kahoot in higher education: Prospective teachers' opinions about teaching with kahoot. National Journal of Education Academy, 3(2), 139-157.

Rienties, B., Brouwer, N., BohleCarbonell, K., Townsend, D., Rozendal, A. P., Loo, J., Dekker, P. \& LygoBaker, S. (2013). Online training of TPACK skills of higher education scholars: a cross-institutional impact study. European Journal of Teacher Education, 36(4), 480-495. https:/ / doi.org/10.1080/02619768.2013.801073

Sanders, K. S. S. (2012). An examination of the academic networking site Edmodo on student engagement and responsible learning [Unpublished Doctoral Dissertation]. University of South Carolina, USA.

Sheffield, R., Dobozy, E., Gibson, D., Mullaney, J., \& Campbell, C. (2015). Teacher education students using TPACK in science: A case study. Educational Media International,52(3), 227-238. https://doi.org/10.1080/09523987.2015.1075104

Siau, K., Sheng, H., \& Nah, F. F. (2006). Use of classroom response system to enhance classroom interactivity. IEEE Transactions on Education, 49(3), 398-403. https:/ / doi.org/10.1109/TE.2006.879802

Tatlı, Z., İpek-Akbulut, H. \& Altınışı, D. (2016). The impact of Web 2.0 tools on pre-service teachers' self confidence levels about TPCK. Turkish Journal of Computer and Mathematics Education, 7(3), 659-678. https://doi.org/10.16949/turkbilmat.277878

The Council of Higher Education [CHE]. (2018). Öğretmen yetiştirme lisans programları [Teacher training undergraduate programs]. Retrieved from https://www.yok.gov.tr/Documents/Kurumsal/egitim_ogretim_dairesi/YeniOgretmenYetistirmeLisan sProgramlari/AA_Sunus_\%20Onsoz_Uygulama_Yonergesi.pdf

Tondeur, J., van Braak, J., Sang, G., Voogt, J., Fisser, P., \& Ottenbreit-Leftwich, A. (2012). Preparing preservice teachers to integrate technology in education: A synthesis of qualitative evidence. Computers $\mathcal{E}$ Education, 59(1), 134-144. https:// doi.org/10.1016/j.compedu.2011.10.009

Tosuntaş, Ş. B., Çubukçu, Z., \& İnci, T. (2019). A holistic view to barriers to technology integration in education. Turkish Online Journal of Qualitative Inquiry, 10(4), 439-461. https://doi.org/10.17569/tojqi.613969

Uğurlu, R. (2009). Investigating the development of prospective mathematics teacher?s knowledge and skills of formative assessment through a program proposed using technological pedagogical content knowledge framework [Unpublished Doctoral Dissertation]. Marmara University, Turkey.

UNESCO. (2006). Using ICT to develop literacy. Bangkok: UNESCO. 
Vannatta, R. A., \& Beyerbach, B. (2000). Facilitating a constructivist vision of technology integration among education faculty and preservice teachers. Journal of Research on Computing in Education, 33(2), 132-148. https:// doi.org/10.1080/08886504.2000.10782305

Virtanen, J., \& Rasi, P. (2017). Integrating Web 2.0 Technologies into face-to-face PBL to support producing, storing and sharing content in a higher education course. Interdisciplinary Journal of Problem-Based Learning, 11(1), 1-12. https:/ / doi.org/10.7771/1541-5015.1613

Yapıc1, İ., \& Karakoyun, F. (2017). Gamification in biology teaching: A sample of Kahoot application. Turkish Online Journal of Qualitative Inquiry, 8(4), 396-414. https:/ / doi.org/10.17569/tojqi.335956

Yıldırım, A., \& Şimşek, H. (2011). Nitel araştırma yöntemleri [Qualitative research methods]. Seçkin.

Yin, R. K. (2011). Applications of case study research. Sage.

Zarzycka-Piskorz, E. (2016). Kahoot it or not? Can games be motivating in learning grammar? Teaching English with Technology, 16(3), 17-36.

Zengin, Y., Bars, M., \& Şimşek, O. (2017). Investigation of using Kahoot! and Plickers in formative evaluation process in mathematics teaching. Ege Journal of Education, 18(2), 602-626. https://doi.org/10.12984/egeefd.318647

Appendix 1

Implementation Process of Assessment and Evaluation Course Supported by Web 2.0 Tools

\begin{tabular}{|c|c|c|c|}
\hline & Topics & Sub-topics & Digital tools \\
\hline Week 1 & $\begin{array}{l}\text { Introduction to Assessment } \\
\text { and Evaluation course }\end{array}$ & $\begin{array}{l}\text { Introducing the digital tools that will } \\
\text { be used in the course }\end{array}$ & Internet \\
\hline Week 2 & $\begin{array}{l}\text { Basic concepts in assessment } \\
\text { and evaluation }\end{array}$ & $\begin{array}{l}\text { Definition and importance of } \\
\text { assessment, types, unit in assessment, } \\
\text { zero, error, scale types }\end{array}$ & $\begin{array}{l}\text { Edmodo } \\
\text { Kahoot! }\end{array}$ \\
\hline Week 3 & $\begin{array}{l}\text { Features to be found in the } \\
\text { assessment tool }\end{array}$ & $\begin{array}{l}\text { Validity, reliability, and usefulness of } \\
\text { assessment tool }\end{array}$ & $\begin{array}{l}\text { Edmodo } \\
\text { Word Art Tagul } \\
\text { I MindMup }\end{array}$ \\
\hline Week 4 & $\begin{array}{l}\text { Measuring behaviors } \\
\text { according to Bloom's } \\
\text { taxonomy }\end{array}$ & $\begin{array}{l}\text { Cognitive, affective and psychomotor } \\
\text { dimensions of Bloom taxonomy }\end{array}$ & $\begin{array}{l}\text { Edmodo } \\
\text { Kahoot! }\end{array}$ \\
\hline Week 5 & $\begin{array}{l}\text { Assessment tools used in } \\
\text { education }\end{array}$ & $\begin{array}{l}\text { Written exams } \\
\text { Oral exams }\end{array}$ & $\begin{array}{l}\text { Edmodo } \\
\text { PollEveryhere }\end{array}$ \\
\hline Week 6 & $\begin{array}{l}\text { Assessment tools used in } \\
\text { education }\end{array}$ & $\begin{array}{l}\text { Multiple-choice tests } \\
\text { True-false tests }\end{array}$ & $\begin{array}{l}\text { Edmodo } \\
\text { Kahoot! }\end{array}$ \\
\hline Week 7 & $\begin{array}{l}\text { Assessment tools used in } \\
\text { education }\end{array}$ & $\begin{array}{l}\text { Matching tests } \\
\text { Short answer tests } \\
\text { Homework and projects }\end{array}$ & $\begin{array}{l}\text { Edmodo } \\
\text { Socrative }\end{array}$ \\
\hline Week 8 & Mid & m Exams & \\
\hline Week 9 & Test development & $\begin{array}{l}\text { Test development steps } \\
\text { Test development }\end{array}$ & $\begin{array}{l}\text { Edmodo } \\
\text { PollEverywhere }\end{array}$ \\
\hline Week 10 & Test development & $\begin{array}{l}\text { Item analysis } \\
\text { Statistics on the final test }\end{array}$ & $\begin{array}{l}\text { Edmodo } \\
\text { Excel }\end{array}$ \\
\hline Week 11 & $\begin{array}{l}\text { Statistical operations on the } \\
\text { assessment results }\end{array}$ & $\begin{array}{l}\text { Measures of central tendency } \\
\text { Measures of central variability }\end{array}$ & $\begin{array}{l}\text { Edmodo } \\
\text { Socrative }\end{array}$ \\
\hline Week 12 & $\begin{array}{l}\text { Statistical operations on the } \\
\text { assessment results }\end{array}$ & $\begin{array}{l}\text { Distribution curves } \\
\text { Standard scores }\end{array}$ & $\begin{array}{l}\text { Edmodo } \\
\text { Google forms }\end{array}$ \\
\hline Week 13 & Evaluating and grading & $\begin{array}{l}\text { Definitions of evaluation } \\
\text { Evaluation types }\end{array}$ & $\begin{array}{l}\text { Edmodo } \\
\text { Padlet }\end{array}$ \\
\hline Week 14 & Evaluating and grading & $\begin{array}{l}\text { Alternative evaluation approaches } \\
\text { Assessment tools used in alternative } \\
\text { evaluation }\end{array}$ & $\begin{array}{l}\text { Edmodo } \\
\text { Padlet }\end{array}$ \\
\hline
\end{tabular}

